\title{
Artefatti cognitivi interattivi web-based: edutainment per il patrimonio culturale
}

\author{
Mara Capone \\ Emanuela Lanzara
}

Abstract

L'utilizzo delle tecnologie digitali per la documentazione e la valorizzazione dei Beni Culturali ha avuto un forte impulso nell'ultimo decennio soprattutto per l'ampia diffusione di strumenti per la modellazione e la realizzazione di immagini immersive e dei dispositivi che consentono la fruizione interattiva a distanza attraverso l'utilizzo della rete. Sempre più numerose sono le sperimentazioni di sistemi integrati multimediali di realtà virtuale, applicazioni immersive, realtà aumentata, Serious Games, etc. che hanno come obiettivo la digitalizzazione elo la ricostruzione virtuale, di manufatti e contesti, e la definizione di strategie in grado di coinvolgere gli utenti stimolando comportamenti attivi. II contributo si colloca in questo ambito e mostra gli avanzamenti di una ricerca in progress finalizzata allo sviluppo di artefatti cognitivi interattivi web-based, fruibili in situ e/o in remoto, con l'obiettivo di trasferire contenuti culturali e stimolare la fruizione partecipata del patrimonio utilizzando modalità 'pseudo-ludiche' (gamification). A scopo esemplificativo, si riportano alcune applicazioni realizzate per la Torre del Partito Nazionale Fascista di Luigi Cosenza (progetto mai realizzato) e per l'Arena Flegrea di Giulio De Luca (edificio demolito e ricostruito), che hanno consentito di affrontare tematiche relative alle diverse possibili esigenze comunicative, di valutare le potenzialità degli strumenti e di sperimentarne la flessibilità.

Parole chiave

realtà virtuale, open data, tour virtuale, gamification, Google Street View.
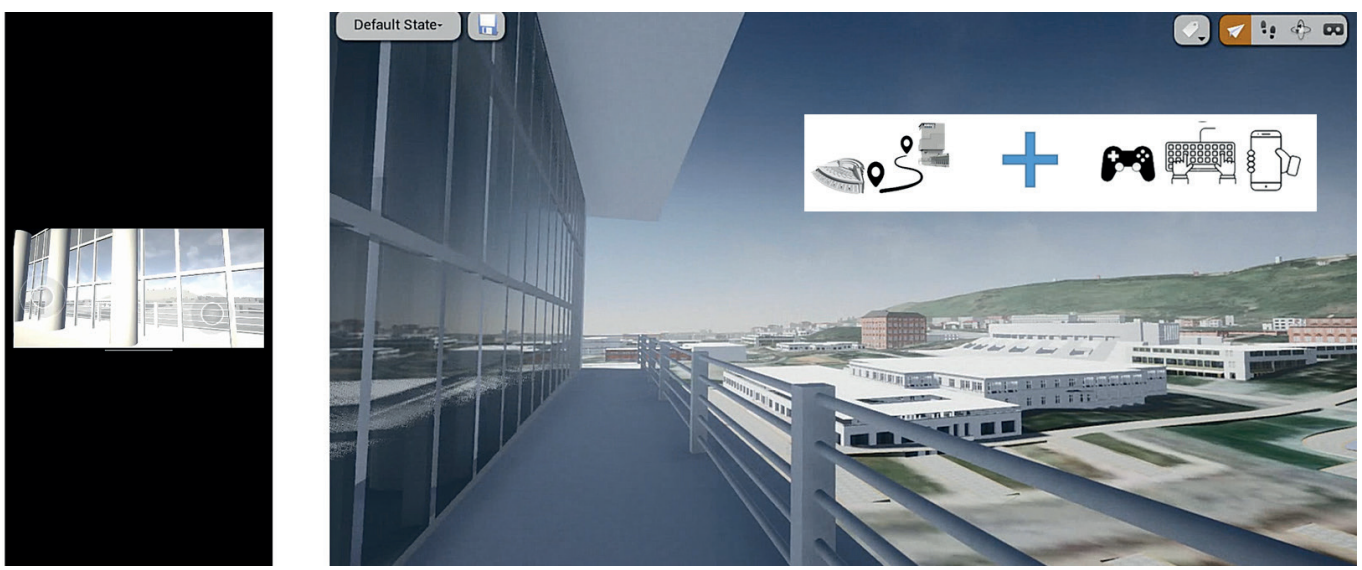
L'utilizzo delle tecnologie digitali per la documentazione e la valorizzazione dei Beni Culturali ha avuto un forte impulso nell'ultimo decennio soprattutto per l'ampia diffusione di strumenti per la modellazione e la realizzazione di immagini immersive e dei dispositivi che consentono la fruizione interattiva a distanza attraverso l'utilizzo della rete. Sempre più numerose sono le sperimentazioni di sistemi integrati multimediali di realtà virtuale, applicazioni immersive, realtà aumentata, serious games, etc. che hanno come obiettivo la digitalizzazione elo la ricostruzione virtuale, di manufatti e contesti, e la definizione di strategie in grado di coinvolgere gli utenti stimolando comportamenti attivi.

La sperimentazione continua e costante in questo ambito ha come denominatore comune la contaminazione dei linguaggi ed il progressivo rinnovo del paradigma comunicativo. Superato l'entusiasmo iniziale per le potenzialità delle tecnologie digitali interattive, la ricerca è sempre più orientata ad individuare forme espressive flessibili ed efficaci, anche in relazione ad una tipologia di utenti eterogenea. II linguaggio iconico è alla base del processo in cui le diverse modalità di visualizzazione contribuiscono attivamente a stimolare la creazione di un'esperienza conoscitiva. Obiettivo della ricerca è quello di contribuire alla consapevole costruzione di un linguaggio digitale coerente con la cultura iconografica piuttosto che sull'utilizzo acritico delle tecnologie, spesso soggette ad una rapida obsolescenza [Capone 20 I I].

Il contributo si colloca in questo ambito e mostra gli avanzamenti di una ricerca in progress finalizzata allo sviluppo di artefatti cognitivi interattivi web-based, fruibili in situ e/o in remoto, con l'obiettivo di trasferire contenuti culturali e stimolare la fruizione partecipata del patrimonio utilizzando modalità 'pseudo-ludiche' (gamification). Lo spazio, declinato attraverso i diversi contesti socio-ambientali che lo caratterizzano, è indagato, scomposto e restituito in risposta alle esigenze d'uso di diverse categorie di utenti [Pascarin 2020]. Attraverso la progettazione di interfacce grafiche tridimensionali customizzabili, l'utente può comprendere il contesto ed esplorarlo in funzione delle modalità a lui note seguendo le 'regole del gioco'. A differenza del tradizionale video nozionistico e unilaterale, che racconta una 'storia' per l'utente che osserva, in questo processo diventa fondamentale individuare opportune strategie di engagement per stimolare il percorso conoscitivo e diffondere modelli innovativi di apprendimento. Basata sulla disciplina del digital storytelling, l'obiettivo è quello di sperimentare forme di rappresentazione interattiva per mettere in connessione gli utenti, che potenzialmente sono tutti coloro che navigano in rete, con la storia del luogo.

L'obiettivo è quello sperimentare la possibilità di realizzare sistemi user friendly, low cost e web-based basati su una tecnologia integrata, sull'interoperabilità tra piattaforme web, app e software open, per la costruzione di modelli fruibili interattivamente e geo-localizzati.

È l'interfaccia grafica che crea e condiziona la user experience dell'utente, che può sperimentare interattivamente, anche in modo immersivo tramite visori VR, gli spazi simulati e comprenderne il significato attraverso una regia che sapientemente articola i diversi stili di visualizzazione passando da simulazioni iper-realistiche ad eteree trasparenze per distinguere il reale dall'ipotetico, il presente dal passato, per veicolare un messaggio o per stimolare la curiosità del visitatore virtuale.

La fruizione in situ di modelli geolocalizzati rende il processo sicuramente più agevole e consente l'immediata contestualizzazione dell'esperienze VR e AR, favorendo la comprensione grazie alla possibilità di sovrapporre il virtuale al reale.

Fig. I. Strumenti e metodi.
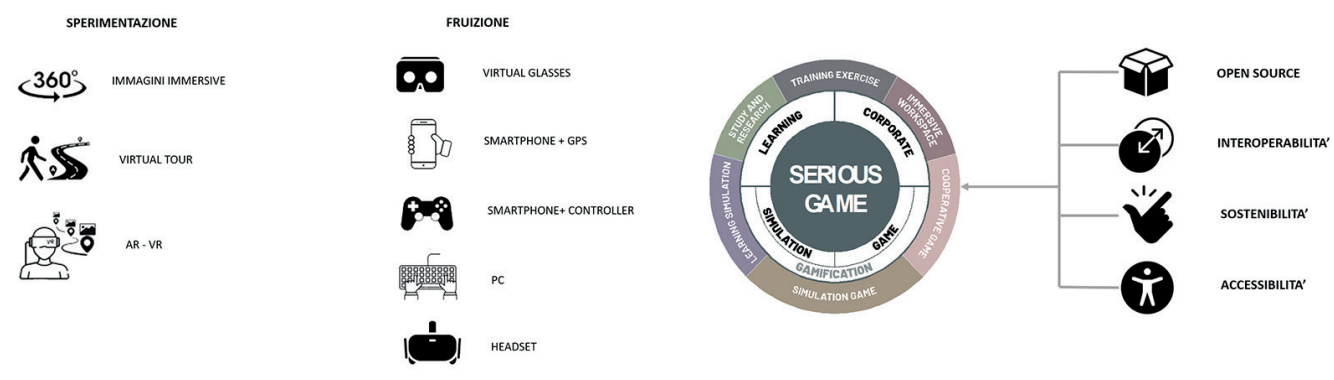

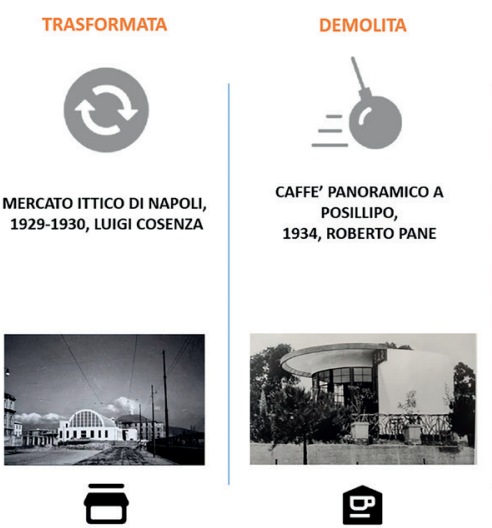

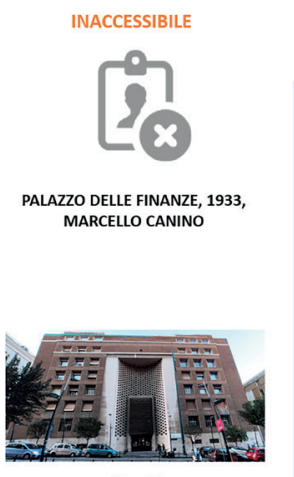

[15]

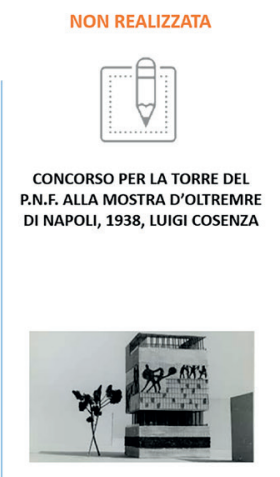

围
RICOSTRUITA

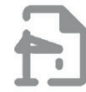

ARENA FLEGREA, MOSTRA D'OLTREMARE DI NAPOLI, 1938, GIULIO DE LUCA

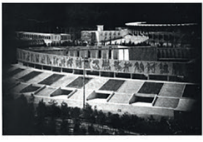

同

\section{Percorso metodologico}

Obiettivo di questo contributo è quello di presentare gli esiti di una sperimentazione per definire un percorso metodologico applicabile a differenti ambiti di ricerca basato sull'utilizzo di tecnologie integrate, adoperabili in situ elo in remoto. La sperimentazione di artefatti comunicativi interattivi geolocalizzati consente la simulazione di un viaggio spazio-temporale, proprio grazie alla contestualizzazione dei modelli architettonici che rappresentano le diverse configurazioni del manufatto, allinterno del reale contesto geografico e urbano di appartenenza. Tali simulazioni favoriscono l'ampia diffusione di artefatti comunicativi realizzabili con strumenti free (web-based) e la pubblicazione dei prodotti su piattaforme open (Google Maps/Street View9), aprendo nuove prospettive di ricerca soprattutto nell'individuazione di un linguaggio divulgativo basato su un approccio scientifico (fig. I).

Le applicazioni possono essere molteplici: sia nell'ambito della valorizzazione del patrimonio culturale che in ambito commerciale (e.g. progettazione di interfacce e-commerce finalizzate a sostenere le attività in remoto).

A scopo esemplificativo, si riportano gli esiti di una ricerca in progress sull'architettura a Napoli tra le due guerra utilizzando due casi studio emblematici: la Torre del Partito Nazionale Fascista di Luigi Cosenza (progetto mai realizzato) e l'Arena Flegrea di Giulio De Luca (edificio demolito e ricostruito) (figg. 2, 3). La scelta di due differenti tipologie ha consentito di affrontare tematiche relative ad alcune delle possibili esigenze comunicative, valutare le potenzialità degli strumenti e sperimentarne la flessibilità.

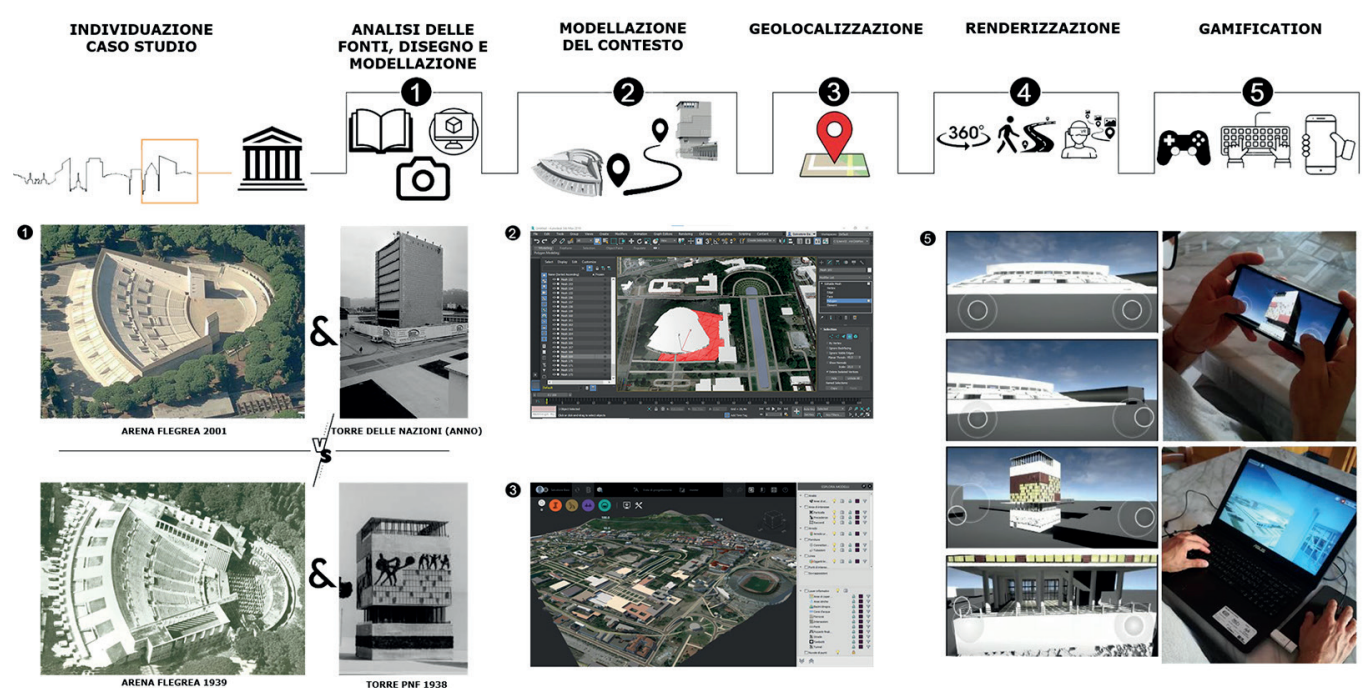


Da un punto di vista metodologico le fasi che hanno caratterizzato la ricerca possono essere così schematizzate:

I. analisi critica delle fonti e dei grafici necessari per la costruzione del modello 3D (fig.5);

2. costruzione del modello 3D (stato fatto, trasformazioni ed eventuali progetti non realizzati) (fig.6);

3. inserimento del modello 3D nel contesto urbano/territoriale di riferimento (acquisizione/composizione modelli territoriali gestione degli open data) (fig. 7);

4. realizzazione di panoramiche $360^{\circ}$ (interne ed esterne) utilizzando diversi stili di visualizzazione per l'individuazione del linguaggio più adatto al caso (trasparenza, wireframe, realistico, ibridi);

5. costruzione del virtual tour per rappresentare la trasformazione;

6. sperimentazione della fruizione web-based: geo-localizzazione e pubblicazione dei virtual tour (Google Maps/Street View);

7. progettazione dello story telling per il concept del serious games (widgets di controllo per la navigazione interattiva del modello, hotspots per l'inserimento di funzioni interattive, etc.).

\section{Linguaggi e tecnologie per rappresentare la trasformazione}

La digitalizzazione del patrimonio culturale comporta la costruzione di modelli 3D, intesi come digital twins, che possono avere un diverso livello di dettaglio (LOD) in relazione all'originale, possono essere visualizzati con modalità diversificate e fruiti con diversi livelli di interattività in funzione dell'utenza e del contesto comunicativo al quale questi modelli sono destinati. L'interfaccia grafica è uno degli elementi fondamentali per l'engagement, da cui dipende il mood che l'utente stabilisce con il sistema. Una grafica poco intuitiva o troppo complessa, potrebbe ostacolare l'esperienza vanificando il processo di apprendimento. Un'interfaccia che risponde ai soli requisiti estetici può essere solo inizialmente attrattiva, mentre un'interfaccia semplice e chiara sarà 'usabile' e quindi consentirà di raggiungere meglio gli obiettivi formativi elo informativi [Carbone 2020].

Il contributo presenta una serie di sperimentazioni realizzate per progettare un'interfaccia grafica tridimensionale interattiva utilizzando diversi livelli di semplificazione, diverse modalità di visualizzazione e di interazione.

\section{Inserimento nel contesto territoriale e gestione degli open data}

Nell'ambito della nostra ricerca, dopo aver costruito il modello 3D e aver definito il linguaggio da utilizzare a seconda dei casi, abbiamo sperimentato alcune delle possibilità esistenti per inserire il modello nel contesto territoriale di riferimento (figg. 6-8).
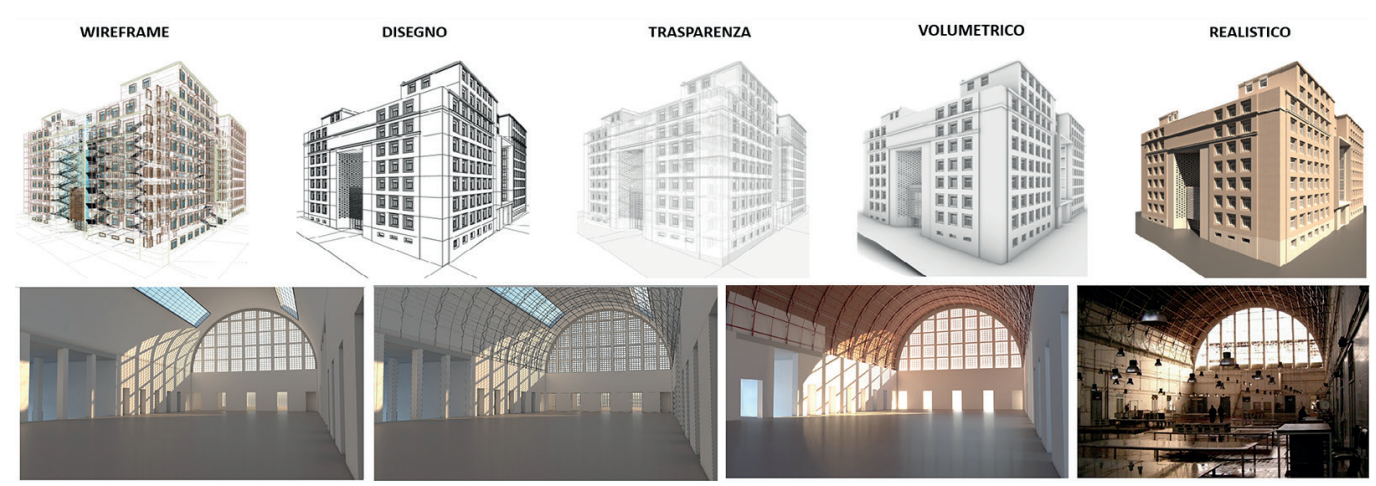
Fig. 5. Analisi critica delle fonti per la costruzione del modello 3D.

Fig. 6. Costruzione de modello 3D.
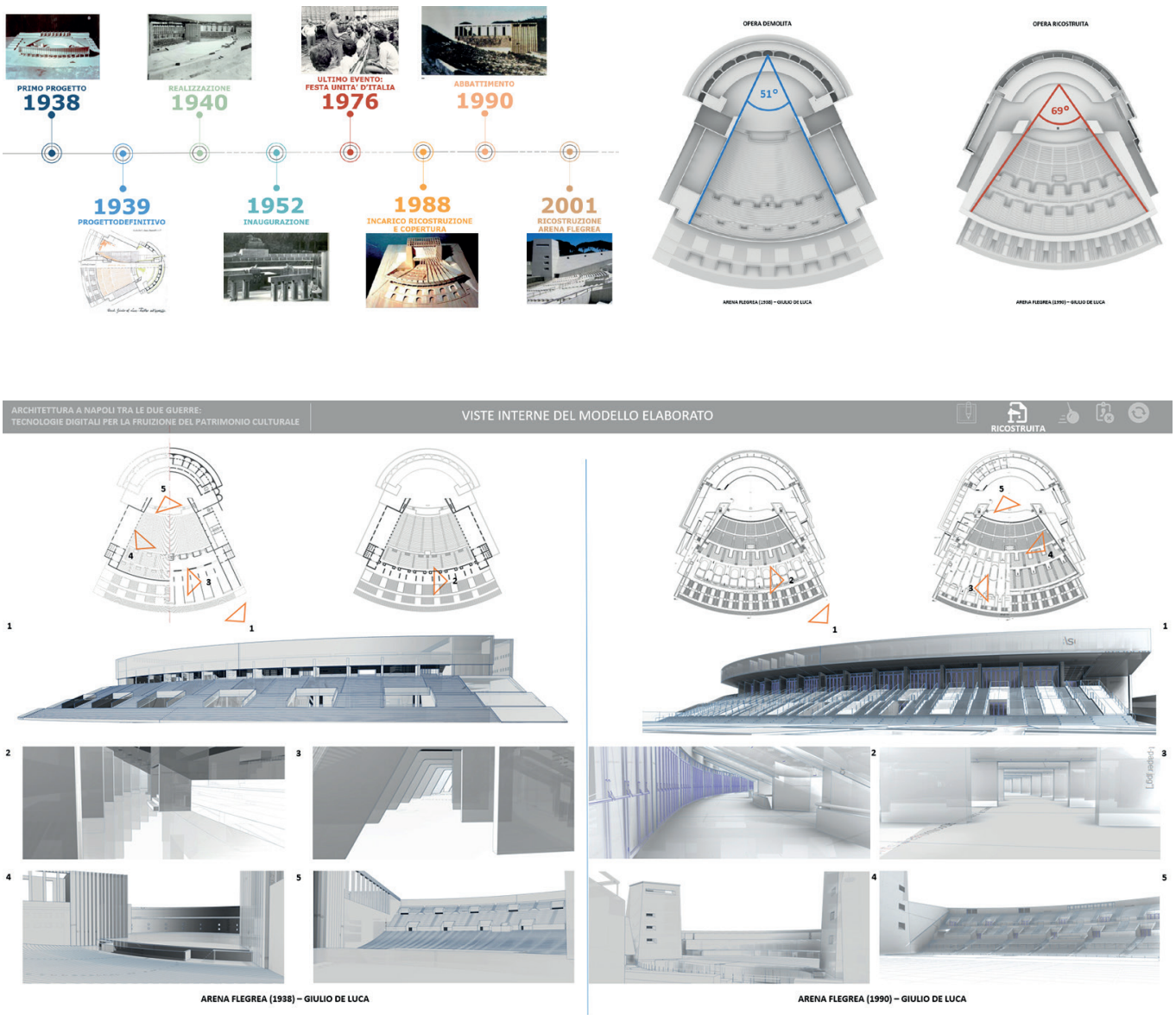

Gli strumenti attualmente disponibili semplificano l'acquisizione, ma soprattutto la manipolazione e la restituzione dei big data territoriali ed urbani sotto forma di un sistema discreto (reti di punti e curve che strutturano i vari elementi e dunque consentono la restituzione dell'orografia, del sistema viario, dell'edificato, etc.) che esplicita e sistematizza le informazioni territoriali contenute in map tiles geo localizzate e disponibili su piattaforme digitali come ad esempio Open Street Map e Shuttle Radar Topography Mission (SRTM).

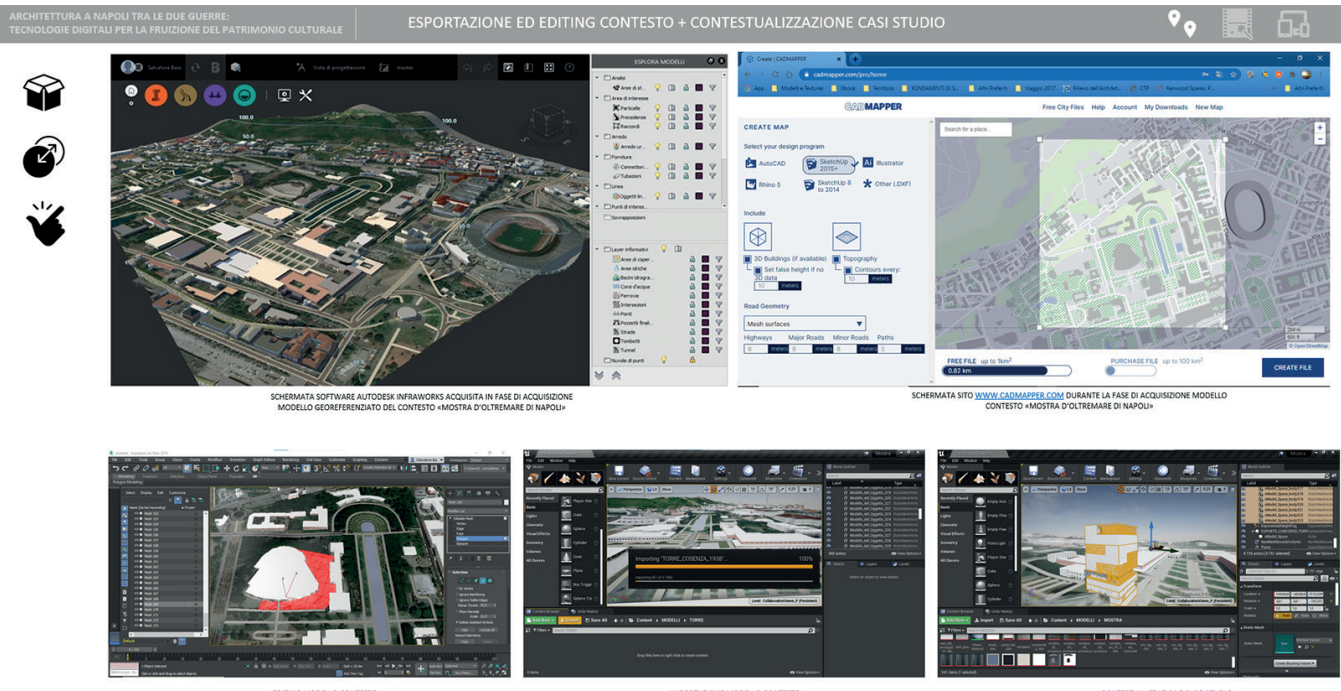


I DEM (Digital Elevation Models) possono essere liberamente scaricati dalle piattaforme, si tratta di dati "grezzi" che si prestano ad una molteplicità di utilizzi, dal routing all'analisi quantitativa del territorio, e opportunamente manipolati, consentono di realizzare mappe per strutturare processi di gamification.

Uno degli obiettivi fondamentali della ricerca è quello di sperimentare l'utilizzo di specifici tools (ad esempio Mosquito, EIK per Grasshopper, Infrawork etc.) per la gestione dei dati open necessari per la costruzione di un modello geo-localizzabile, customizzabile e navigabile.
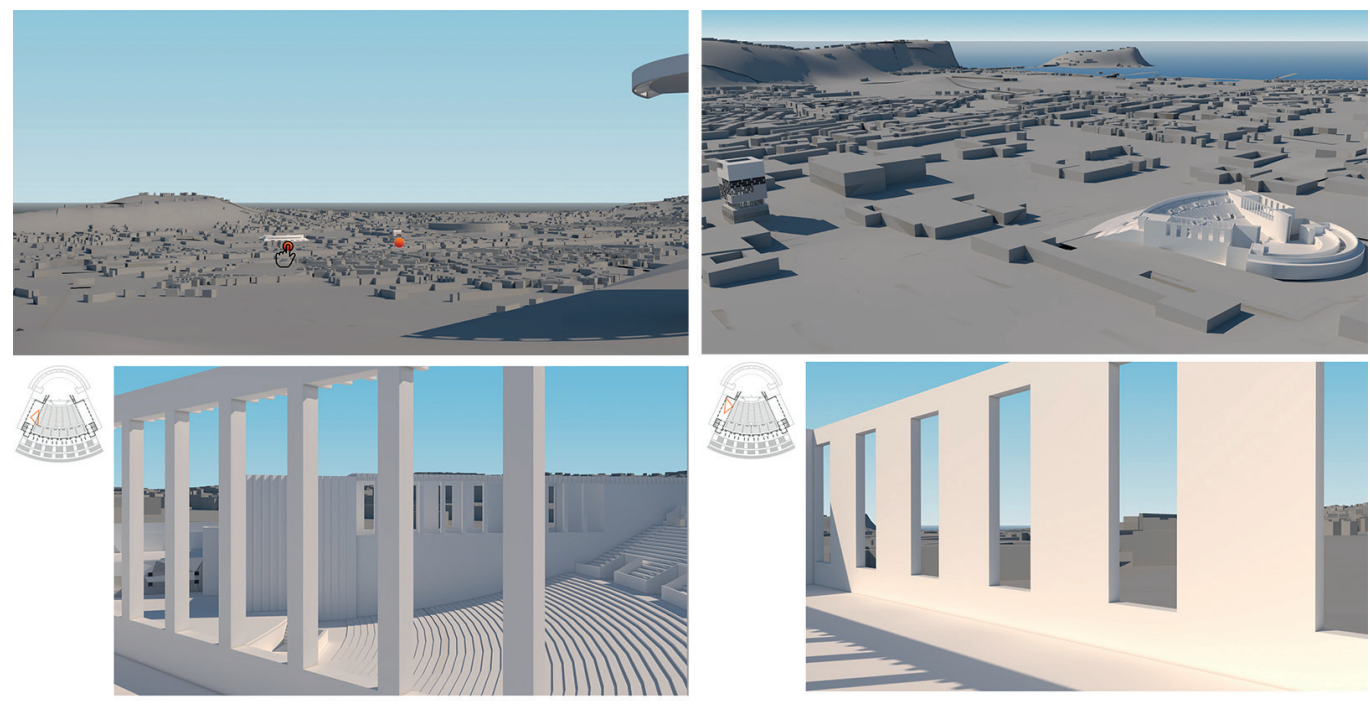

\section{Fruizione immersiva del contesto e web sharing}

La costruzione di tour virtuali è una pratica ormai estremamente diffusa in diversi ambiti e presuppone la realizzazione di un insieme di foto, o render $360^{\circ} \mathrm{che}$, collegate tra loro, consentono l'esplorazione interattiva anche in modalità immersiva [Checa 2020] utilizzando visori o virtual glasses (fig. 10). I Virtual Tour Software consentono di creare tour virtuali anche senza conoscenze specifiche nel settore informatico. II software, implementato di specifiche funzionalità, spesso disponibili attraverso relative piattaforme, consente l'inserimento di contenuti multimediali, ad esempio menu, hotspot descrittivi, connessione con plug-in che consentono di costruire sistemi di prenotazione o di acquisto on-line (e-commerce), offrono la possibilità di rilasciare commenti, etc.

La sperimentazione consiste nell'esplorare le potenzialità di questo strumento di rappresentazione in modo critico. Generalmente l'utilizzo di immagini immersive ha come obiettivo quello di simulare uno spazio per consentirne la fruizione interattiva in remoto. Le immagini utilizzate per generare il virtual tour sono foto reali o generalmente render fotorealistici in quanto l'obiettivo è quello di simulare la percezione di uno spazio reale e quindi con un livello di verosimiglianza molto elevato.

In particolare, l'uso di stili di visualizzazione differenti per la creazione di render sferici consente modalità di visualizzazione interpretative della realtà.

Alcuni software presenti in commercio, particolarmente performanti, consentono di navigare direttamente all'interno dei modelli di contesti ambientali o edifici. Tuttavia, questo vantaggio non consente di passare da uno stile di visualizzazione all'altro, operazione necessaria e utile per sovrapporre configurazioni che consentono la comprensione del percorso evolutivo del bene, il confronto tra uno stato di fatto e una configurazione trasformata nel tempo o un progetto non realizzato, uno stato non più esistente o mai esistito.

Nell'ambito della ricerca abbiamo testato alcuni tra i software più accessibili e di semplice utilizzo quale Google tour creator che consente l'up-load di sferiche allinterno di un con- 
Fig. 9. Panoramiche $360^{\circ}$ : sperimentazione dei diversi stili di visualizzazione realistico, ibridi).
Fig. 10. Virtual tours per rappresentare la per rappresentare

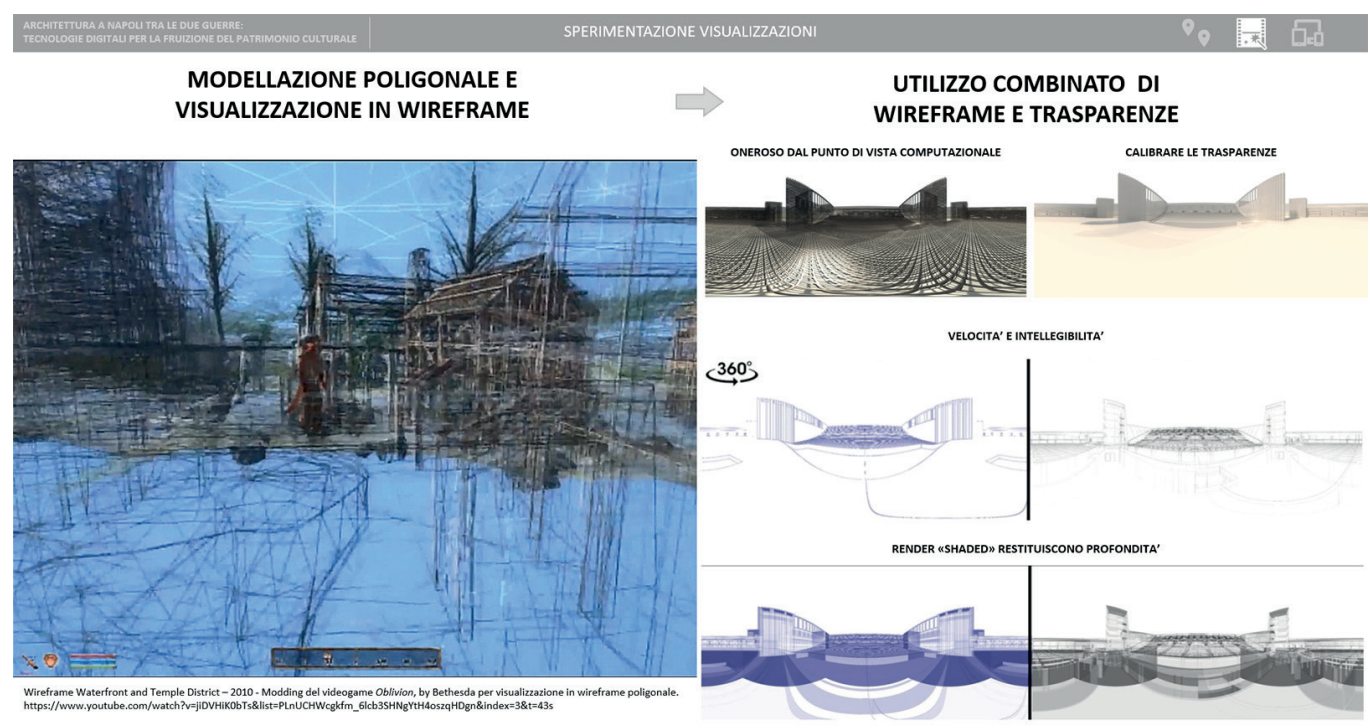

testo ambientale esistente, dunque geo-localizzabili in Google Maps. La maggior parte di questi software consente di collegare alle sferiche caricate altri contenuti informativi, quali ad esempio testi e immagini. II passaggio da uno stile di visualizzazione all'altro consente di scegliere come visualizzare il modello, semplificando o rivelando relazioni non immediatamente apprezzabili tra gli spazi e gli elementi che lo compongono.

Sono state esplorate alcune delle potenzialità della piattaforma Tourmake, molto utilizzata a scopi commerciali, che tramite Viewmake Editor, consente di pubblicare tour virtuali su Google StreetView, geo-localizzandoli e rendendoli così accessibili a tutti. Questa applicazione consente di percorrere un tour virtuale in modalità Street View, ma all'interno di un contesto trasformato rispetto allo stato di fatto reale (interamente ricostruito, modificato, aumentato) (fig. I I). La percorribilità è consentita dal montaggio di un tour composto da più 'spazi' (render o foto 360) in successione. La creazione di un tour virtuale customizzato si realizza utilizzando gli strumenti aggiuntivi disponibili, quali markers, links, hotspot, che consentono di localizzare le sferiche all'interno della mappa (geolocalizzazione) e di implementarle con informazioni
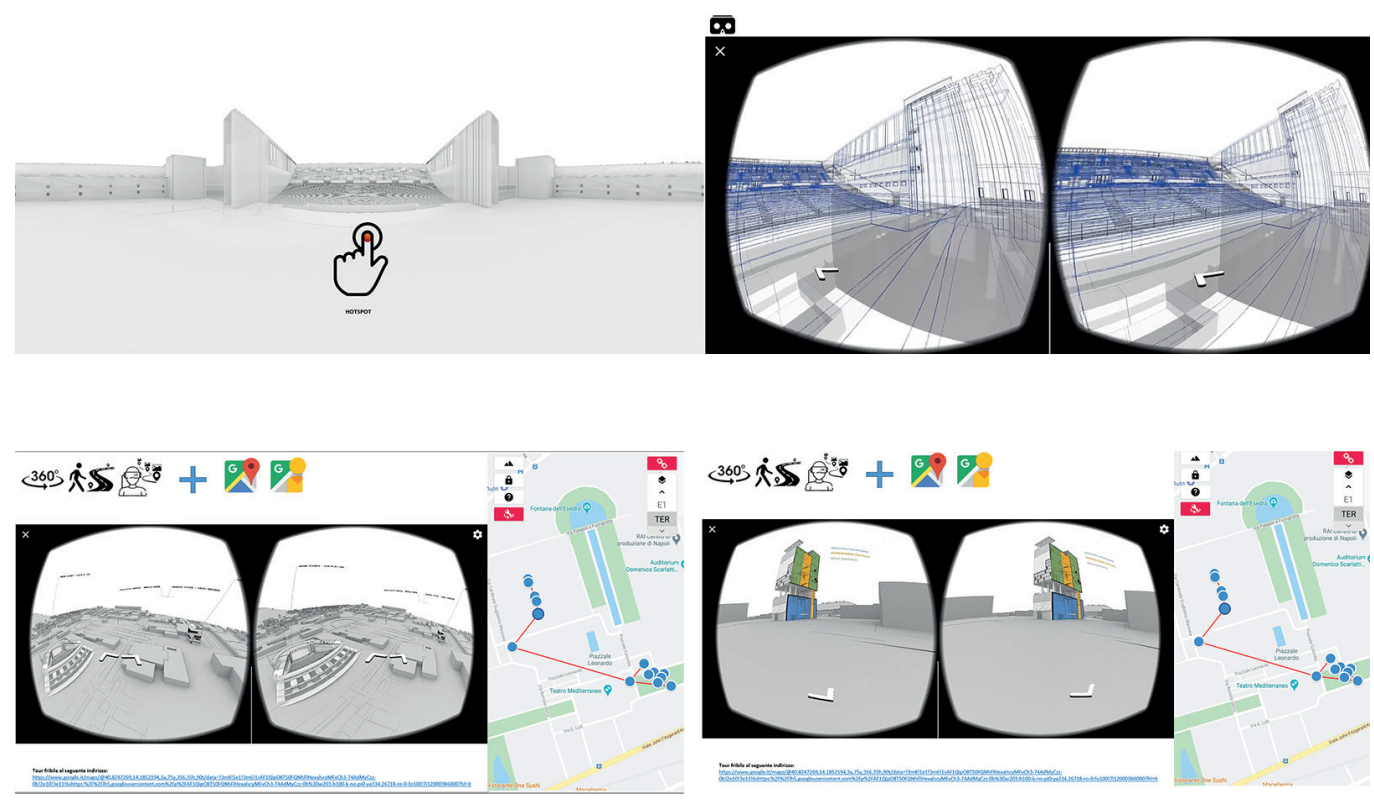

Fig. II. Web sharing sperimentazione della fruizione web based: geo-localizzazione e pubblicazione dei virtual tour su Google Maps/ Street View. 
che arricchiscono la fruizione del bene, di un contesto ambientale, o della relazione tra i due. Per costruire un tour è necessario individuare la location di riferimento in Google Map e importare le sferiche direttamente dal proprio device all'interno dell'app. Una volta selezionata la sferica di partenza tra quelle caricate all'interno del device e scelto il punto di vista da cui si vuole fruire l'ambiente rispetto ad una data posizione di partenza all'interno del contesto (starting point del tour virtuale) tutte le sferiche successive che compongono il tour saranno posizionate in funzione del percorso e occuperanno una specifica posizione con uno specifico orientamento rispetto alla sferica di partenza. II tour virtuale predisposto può essere pubblicato sulla piattaforma Google Maps/Street View è quindi sarà fruibile da tutti i browser web, direttamente accessibile mediante specifico indirizzo, su dispositivi mobili e su personal computer in situ e in remoto.

Nell'ambito della ricerca, per valutare l'interoperabilità, sono state condivise alcune prove di simulazione che sono state rese accessibili su Google maps, attivando la modalità Street all'indirizzo Napoli, Mostra d'Oltremare, Viale Kennedy (fig. I I).

\section{Conclusioni e futuri sviluppo della ricerca}

Obiettivo della ricerca è quello di costruire strutture informative web-based che consentano di rappresentare la storia di un sito utilizzando linguaggi, livelli di semplificazioni e di interazione modulabili in funzione dell'utente elo del contesto. Oggetto di studio e approfondimento futuro è l'utilizzo di alcuni plug-in esistenti che consentono di interagire con il modello mediante appositi widget di controllo predefiniti, game controller touch, per sperimentare le modalità di comunicazione tipiche dei games (fig. 12) [Khan 2020]. In questo ambito la nostra ricerca intende esplorare diverse modalità di engagement in grado di stimolare la comprensione dei contenuti culturali connessi al patrimonio e al contesto.
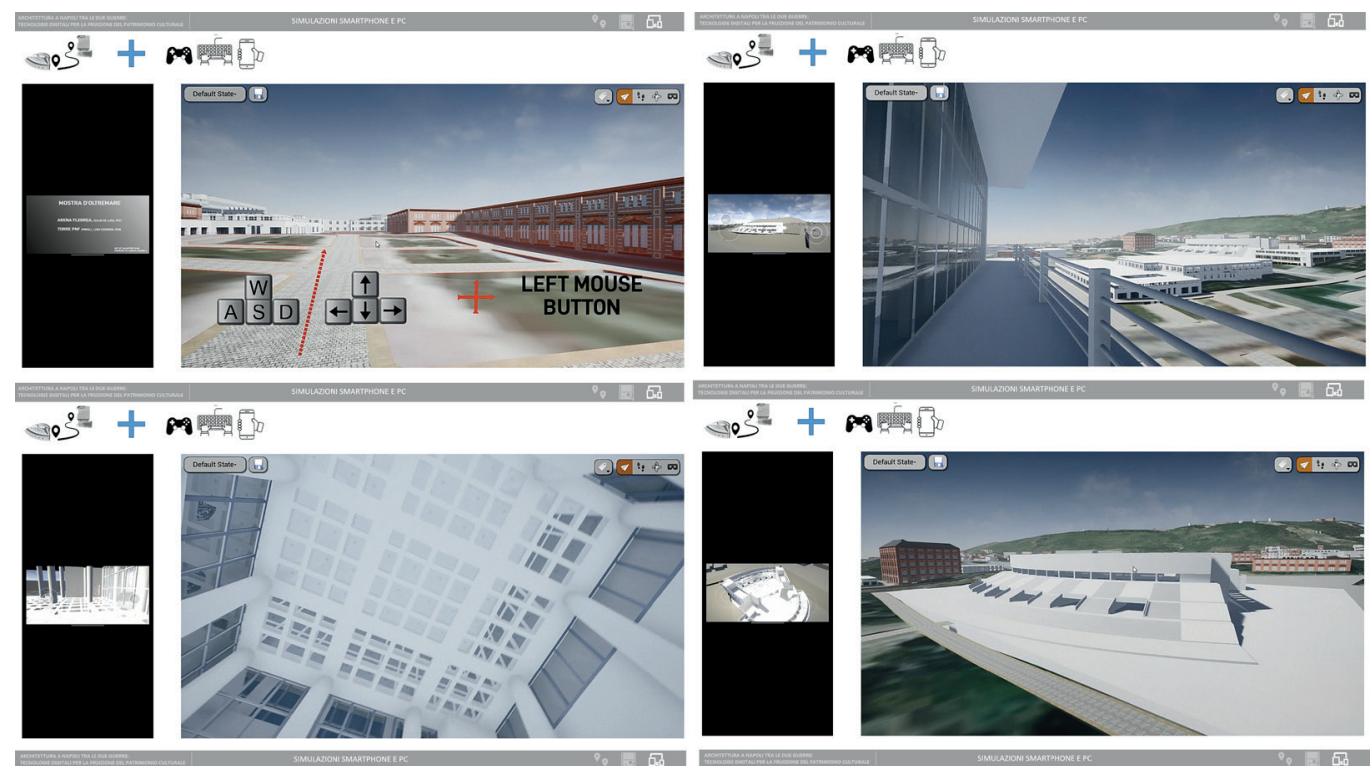

Fig. 12. Fruizione interattiva con modalità 'ludica' della Mostra dentro la Torre del Partito Nazionale Fascista (progetto non realizzato) (progetto non realizzato) elArena Flegrea (edificio demolito)

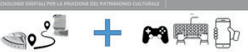

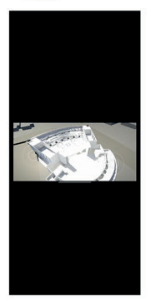

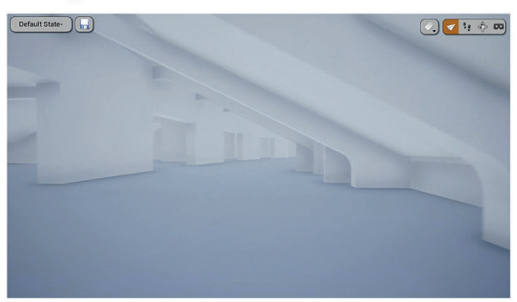
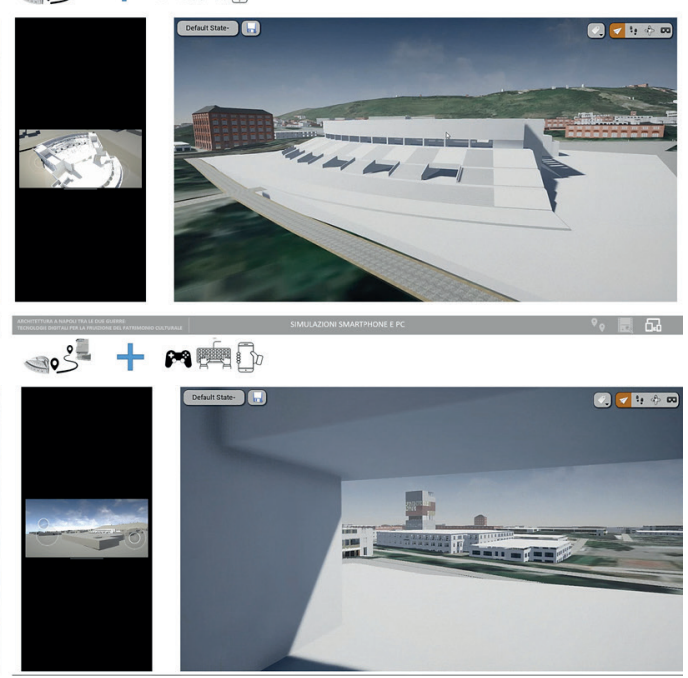


\section{Riferimenti bibliografici}

Carbone M. (2020). L'interfaccia uomo macchina nell'Industria 4.0. <https://www.industry4business.it/industria-4-0/linterfaccia-uomo-macchina-nellindustria-4-0/ > (consultato il 20 maggio 202I).

Checa D., Bustillo A. (2020). A review of immersive virtual reality serious games to enhance learning and training. In Multimedic Tools and Applications, n.79(9- I0), pp. 550 I-5527. <https://doi.org/I0.1007/s I I042-019-08348-9> (consultato il 20 maggio 202I).

Khan I., Melro A., Amaro A.C., Oliveira L. (2020). Systematic Review on Gamification and Cultural Heritage Dissemination. In Journal of Digital Media \& Interaction, vol. 3, n. 8, pp. 19-4l.

Mortara M., Catalano C. E. (20 18). 3D Virtual environments as effective learning contexts for cultural heritage. In Italian Journal of Educational Technology, n.26(2), pp. 5 -2 I. < https://doi.org/l 0.1747//2499-4324/I026> (consultato il 20 maggio 202 I).

Pescarin S. (2020). Videogames, ricerca, patrimonio culturale. Milano: FrancoAngeli.

Interfacce grafiche, dinamiche e gamification. (2I luglio 2020). <https://www.gamification.it/gamification/interfacce-grafiche-dinamiche-e-gamification/\#more-> (consultato il 20 maggio 202I).

\section{Autori}

Mara Capone, Università degli Studi di Napoli Federico II, mara.capone@unina.it

Emanuela Lanzara, Università degli Studi di Napoli Federico II, emanuela.lanzara@unina.it

Per citare questo capitolo: Capone Mara, Lanzara Emanuela (202I). Artefatti cognitivi interattivi web-based: edutainment per il patrimonio culturale/Web-based Interactive Cognitive Artifacts: Edutainment for Cultural Heritage. In Arena A., Arena M., Mediati D., Raffa P. (a cura di). Connettere. Linguaggi Distanze Tecnologie. Atti del $42^{\circ}$ Convegno Internazionale dei Docenti delle Discipline della Rappresentazione/Connecting. Languages Distances Technologies. Proceedings of the 42th International Conference of Representation Disciplines Teachers. Milano: FrancoAngeli, pp. 2119 -2 136. 


\title{
Web-based Interactive Cognitive Artifacts: Edutainment for Cultural Heritage
}

\author{
Mara Capone \\ Emanuela Lanzara
}

Abstract

The use of digital technologies for the documentation and enhancement of Cultural Heritage has had a strong impulse in the last decade, above all due to the wide diffusion of tools for modeling and creation of immersive images and devices that allow interactive use in remote.

Experiments with integrated multimedia systems of virtual reality, immersive applications, augmented reality, Serious Games, etc. that have as their objective the digitization and/or virtual reconstruction of artefacts and contexts, and the definition of strategies capable of involving users by stimulating active behaviors, are increasingly numerous.

In this context, our contribution shows the progress of a research in progress aimed at interactive web-based cognitive artefacts development, usable in situ and / or in remote, with the aim of cultural contents dissemination using 'pseudo-playful' modes (gamification).

Using two case studies, the Tower of the National Fascist Party by Luigi Cosenza (project never built) and the Arena Flegrea by Giulio De Luca (building demolished and rebuilt), we addressed issues relating to different communication needs, in order to evaluate the potential of tools and to test their flexibility.

Keywords

virtual reality, open data, virtual tour, gamification, Google Street View.
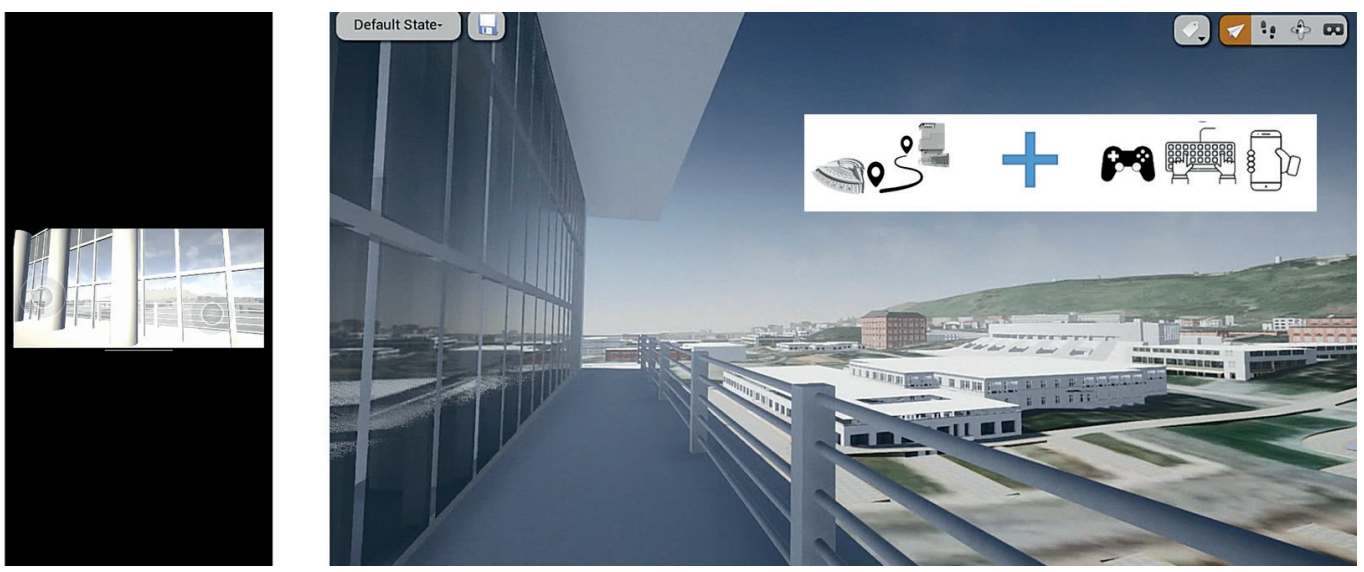
The use of digital technologies for the documentation and enhancement of Cultural Heritage has had a strong impulse in the last decade, above all due to the wide diffusion of tools for modeling and creation of immersive images and devices that allow interactive use in remote.

Experiments with integrated multimedia systems of virtual reality, immersive applications, augmented reality, Serious Games, etc. that have as their objective the digitization and / or virtual reconstruction of artefacts and contexts, and the definition of strategies capable of involving users by stimulating active behaviors, are increasingly numerous.

Continuous and constant experimentation in this area has encouraged languages contamination and communicative paradigm renewal process.

After the initial enthusiasm for interactive digital technologies potentiality, research is increasingly oriented towards identifying flexible and effective expression forms in relation to different users.

The iconic language is the basis of the process in which different visualization modes actively contribute to generate a cognitive experience.

The research aim is to develop a digital language based on iconographic culture rather than uncritical use of technologies, often subject to fast obsolescence [Capone $20 \mathrm{II}$ ].

In this context, our contribution shows the progress of a research in progress aimed at interactive web-based cognitive artefacts development, usable in situ and / or in remote, with the aim of cultural contents dissemination using 'pseudo-playful' modes (gamification). Through the design of customizable three-dimensional graphic interfaces, the user can understand the context and explore it according to the methods known to him by following the "rules of the game" [Pascarin 2020].

Unlike the traditional one-sided notional video, which tells a 'story' for the user who observes, in this process it becomes essential to identify appropriate engagement strategies to stimulate the cognitive path and disseminate innovative learning models. Based on the discipline of digital storytelling, the goal is to experiment with forms of interactive representation to connect users, all web users, with the history of the place.

The goal is to test the possibility of creating user friendly, low cost and web-based systems based on integrated technology, on the interoperability between web platforms, apps and open software, for the construction of interactively usable and geo-localized models.

The graphic interface creates and conditions the user experience, who can interactively experiment, even in an immersive way through $V R$ viewers, the simulated spaces and understand their meaning through a direction that skillfully articulates the different visualization styles to distinguish the real from the hypothetical, the present from the past, to convey a message or to stimulate the curiosity of the virtual visitor.

The use of geo-localized models in situ certainly makes the process easier and allows the immediate contextualization of the VR and AR experiences, favoring understanding thanks to the possibility of overlapping the virtual on the real.
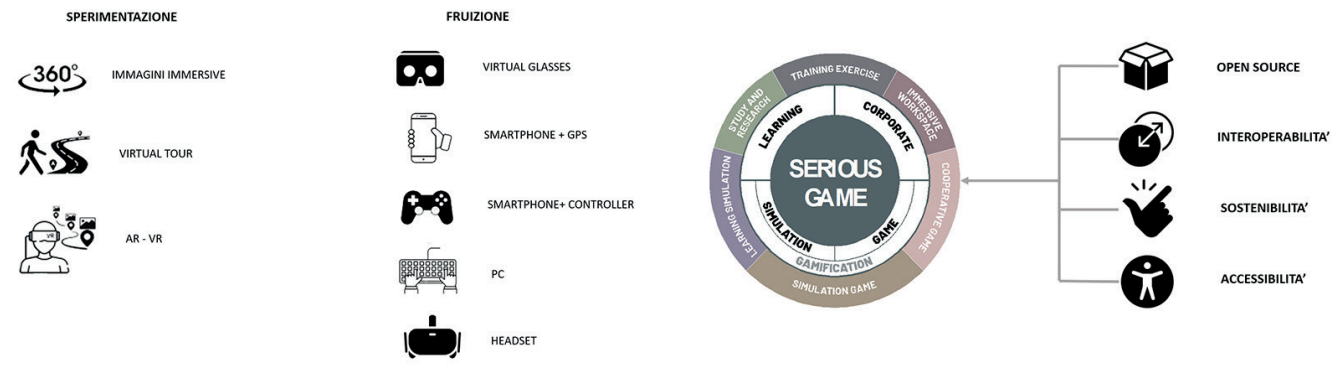
Fig. 2. Architecture in Naples between the two Wars: case studies for Serius Game simulation.
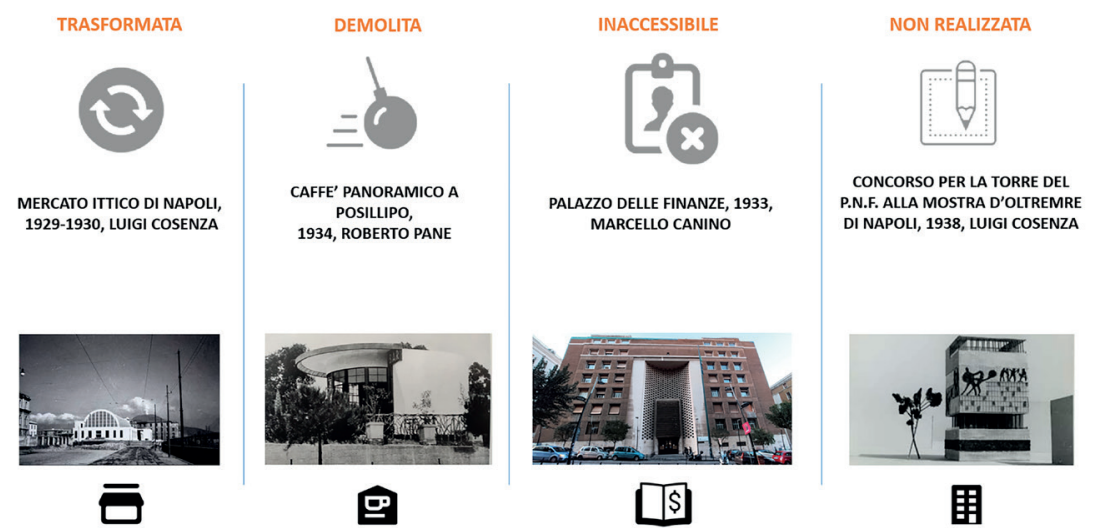

RICOSTRUITA

围

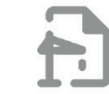

ARENA FLEGREA, MOSTRA D'OLTREMARE DI NAPOLI, 1938, GIULIO DE LUCA

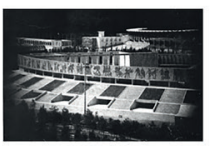

同

\section{Methodological path}

The aim of this contribution is to present the results of an experiment to define a methodological path applicable to different research fields based on the use of integrated technologies, which can be used in situ and/or remote. The experimentation of geo-localized interactive communicative artifacts allows the simulation of a space-time journey, thanks to the contextualization of the architectural models that represent the different constructions of the artifact, within the real geographical and urban context of belonging. These simulations favor the wide diffusion of communicative artefacts achievable with free tools (web-based) and the publication of products on open platforms (Google Maps / Street View9), opening new research perspectives especially in the identification of a popular language based on a scientific approach (fig. I).

There are many applications both in the field of cultural heritage enhancement and in the commercial field (e.g. design of e-commerce interfaces aimed at supporting remote activities).

Using two case studies, the Tower of the National Fascist Party by Luigi Cosenza (project never built) and the Arena Flegrea by Giulio De Luca (building demolished and rebuilt), we addressed issues relating to different communication needs, in order to evaluate the potential of tools and to test their flexibility (figs. 2, 3).

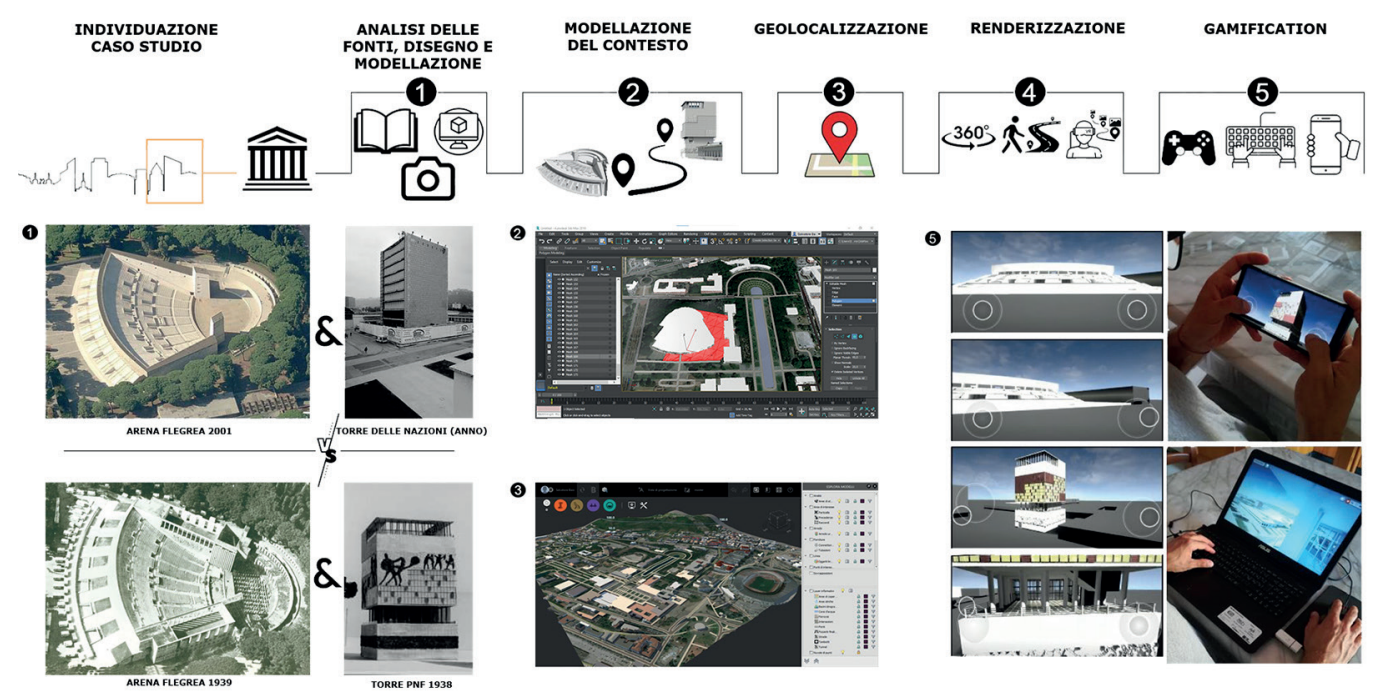


The main steps of methodological path are:

I. critical analysis of the sources and drawings for 3D model (fig. 5);

2. $3 \mathrm{D}$ model construction (state of the art, transformations and any unrealized projects) (fig.6);

3. georefereced 3D model (territorial models and management of open data) (fig. 7);

4. $360^{\circ}$ panoramas (inside and outside) using different visualization styles to identify the best language to use (transparency, wireframe, realistic, hybrid);

5. virtual tour to represent the transformation;

6. web-based use tests: georeference and publication of virtual tours (Google Maps / Street View);

7. storytelling design for 'serious games' concept (control widgets for interactive model navigation, hotspots for interactive functions, etc.).

\section{Languages and technologies torepresent transformation}

The digitization of cultural heritage involves the construction of 3D models, intended as digital twins, which can have a different level of detail (LOD) in relation to the original, can be visualized in different ways and enjoyed with different levels of interactivity in relation to users and communicative context to which these models are intended.

The graphic interface is one of the main elements for engagement, on which the mood that the user establishes with the system depends.

Too complex graphics could hinder the experience and frustrate the learning process. An interface that meets only the aesthetic requirements can only be initially attractive, while a simple and clear interface will be 'usable' and therefore will allow you to better achieve the training and / or information objectives [Carbone 2020]. The contribution presents a series of experiments carried out to design an interactive 3D graphic interface using different levels of simplification, different viewing and interaction modes. The contribution presents a series of experiments carried out to design an interactive 3D graphic interface using different levels of simplification, different viewing and interaction modes.

\section{Insertion in the territorial context and open data management}

In our research, we built 3D model, we defined the visualization mode and we tested different ways to insert 3D model in the reference territorial context (figs. 6-8).

The tools currently available simplify the acquisition, the use of territorial and urban big data in the form of a discrete system (networks of points and curves that structure the various
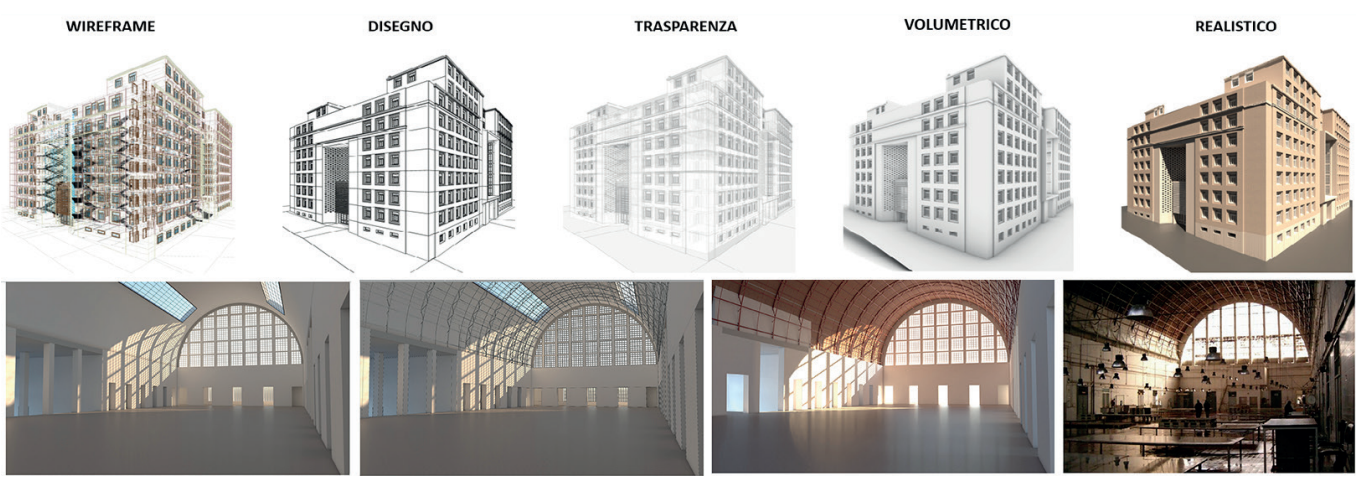
Fig. 5. Critical analysis of the sources for 3D modelling.

Fig. 6. 3D modelling.
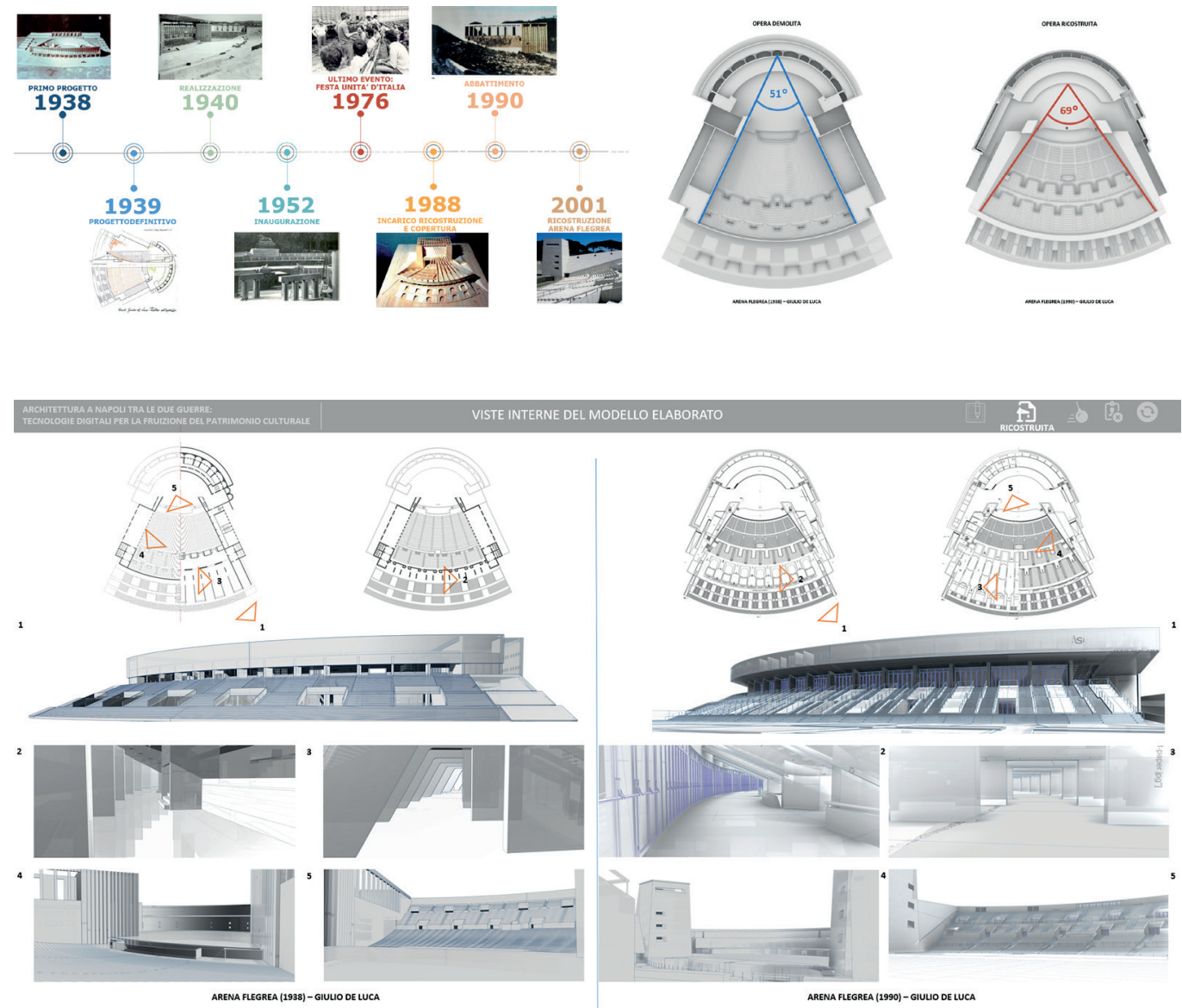

elements and therefore allow the return of the orography, the road system, the edified, etc.) that explains and systematizes the territorial information contained in geolocated map tiles and available on digital platforms such as Open Street Map and Shuttle Radar Topography Mission (SRTM).

DEM (Digital Elevation Models) can be freely downloaded from the platforms, these are "raw" data that lend themselves to a multiplicity of uses, from routing to quantitative

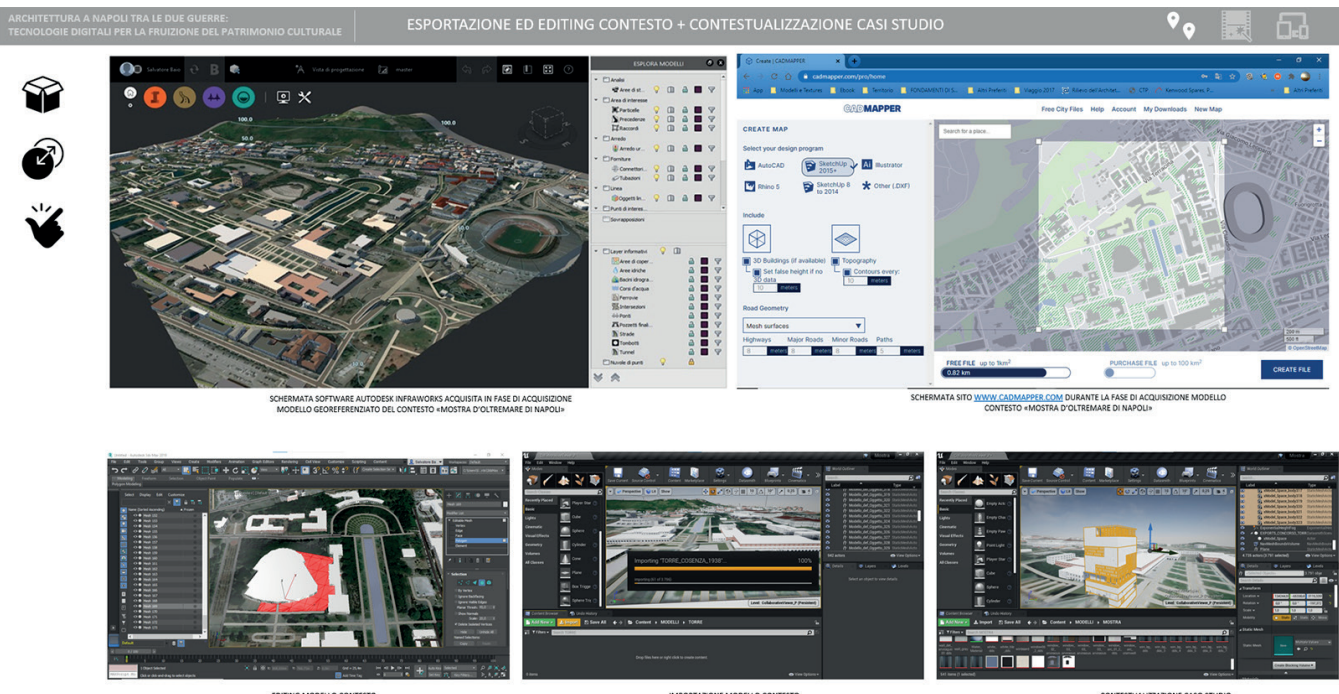


Fig. 8. Interactive use of the model in the territorial context: the building in the context_the building as a perceptive device. territoryanalysis, and appropriately manipulated, allow the maps creation for gamification processes.

One of the main research goal is to experiment with the use of specific tools (for example Mosquito, EIK for Grasshopper, Infrawork etc.) for open data management to generate a georeferenced, customizable and navigable 3D model.
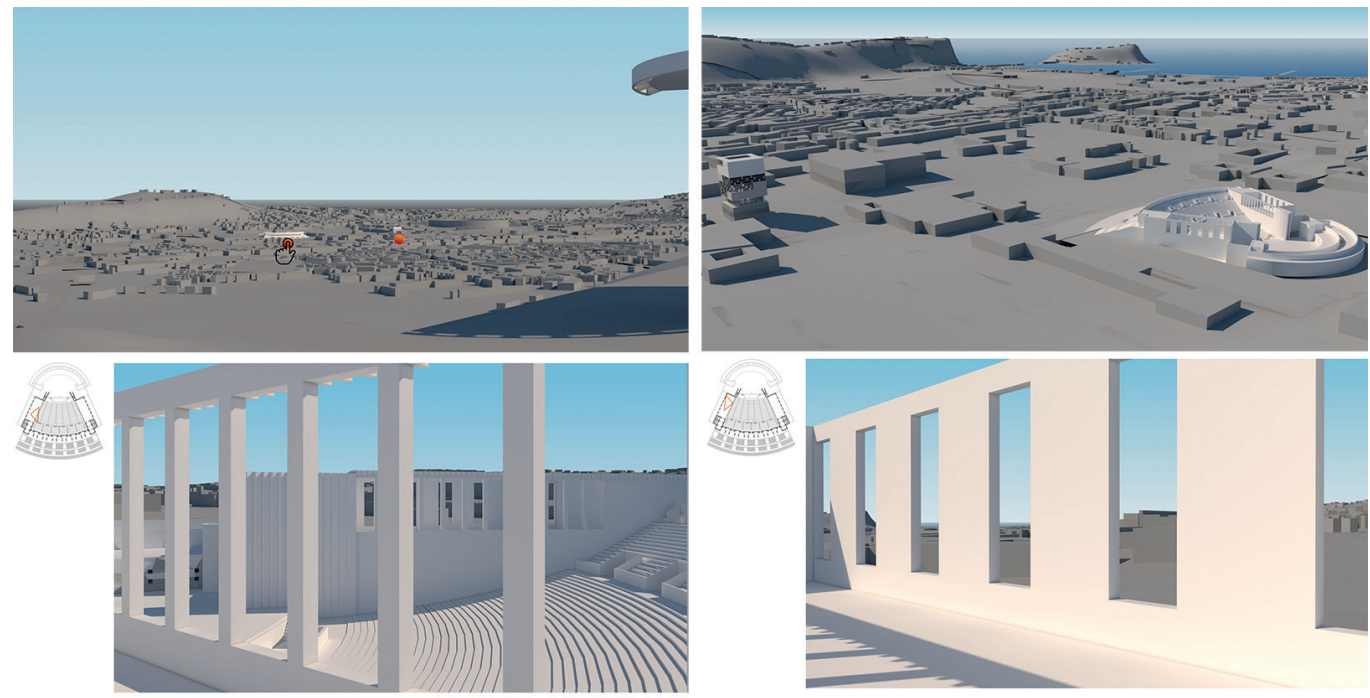

\section{Immersive use of the context and web sharing}

'Virtual tours' is a widespread practice in different areas and requires the creation of a set of photos, or $360^{\circ}$ renderings which, connected to each other, allow interactive exploration even in immersive mode [Checa 2020] using viewers or virtual glasses (fig. I0).

Virtual Tour Software allow you to create virtual tours even without specific knowledge in the IT sector. The software, implemented with specific functions, often available through relative platforms, allows the insertion of multimedia contents, for example menus, descriptive hotspots, connection with plug-ins that allow you to build booking or online purchasing systems (and commerce), offer the possibility to leave comments, etc. Experimentation consists in exploring the potential of this representation tool in a critical way. Usually the use of immersive images aims to allow remote interactive use of a place. The images used to generate the virtual tour are generally real photos or photorealistic renderings because the goal is to simulate the perception of a real space. The use of different visualization styles to generate $360^{\circ}$ renderings allows you to represent different interpretations of reality.

There are some software that allow in to navigate 3D models inside and outside. However, these software do not allow you to switch from one display mode to another, this is necessary to represent transformations or unrealized projects, what no longer exists or has never existed.

In our research, we tested some of the most common and easy-to-use software, such as Google Tour Creator, that allows to upload $360^{\circ}$ panorama in a territorial context, therefore geo-localizable in Google Maps.

Most of these software allow you to link other information, such as text and images, to $360^{\circ}$ images. Some of the potential of the Tourmake platform, widely used for commercial purposes, has been explored. View Make Editor allows you to publish a virtual tour on Google Street View, in this way it is accessible to everyone. This is an easy-to-use tool that 


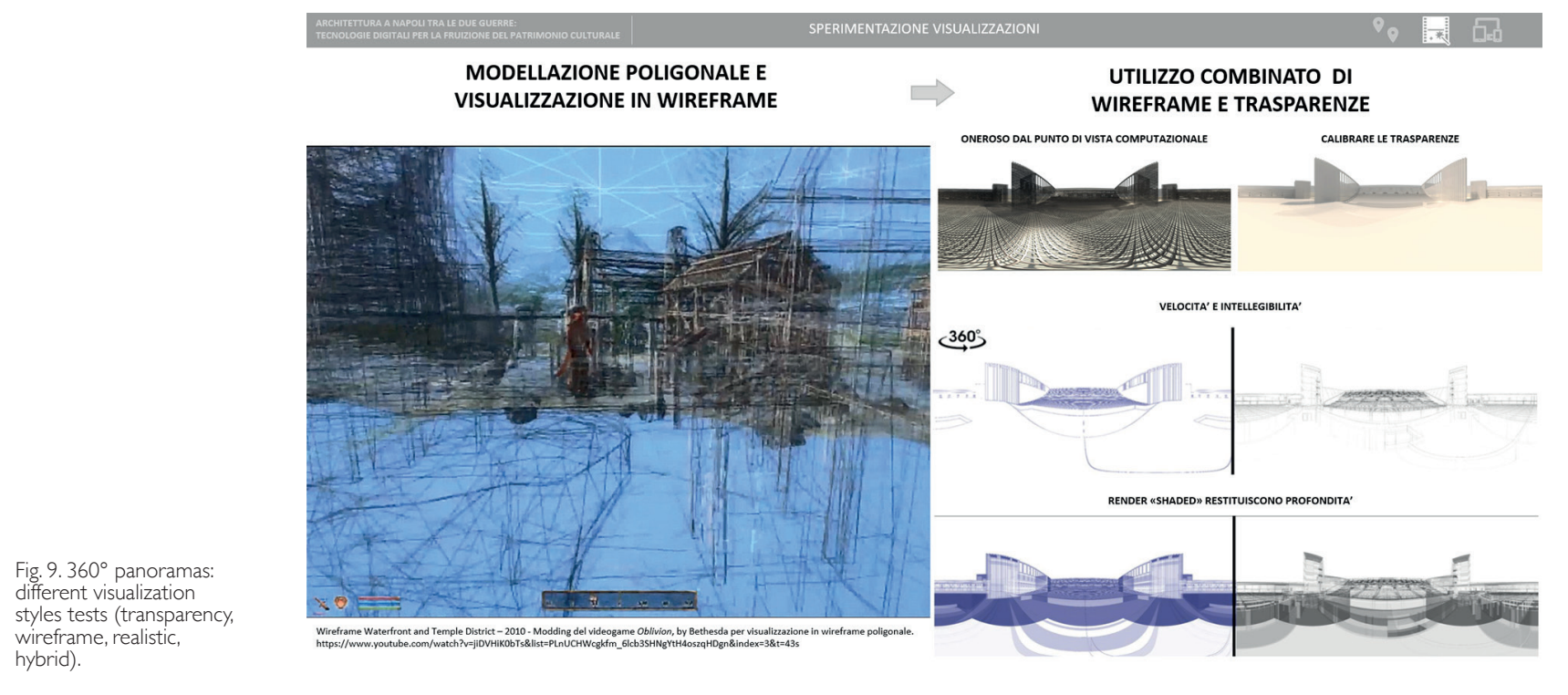

allows you to create $360^{\circ}$, like Street View, but within a context transformed in relation to reality (fig. I I).

The customized virtual tour is made using the additional tools available, such as markers, links, hotspots, which allow you to locate the panoramas within the map (geolocation) and implement them with information that enriches knowledge.

To take a tour, you need to identify the location in the Google Map and to upload the $360^{\circ}$ panorama from your device within the app.

Once you have selected the starting $360^{\circ}$ panorama and the virtual tour starting point, all $360^{\circ}$ panoramas will be localized according to the route with a specific orientation in relation to the starting image. The virtual tour can be published on the Google Maps / Street View platform and can be shared by all web browsers using mobile devices and personal computers, in situ and remotely.
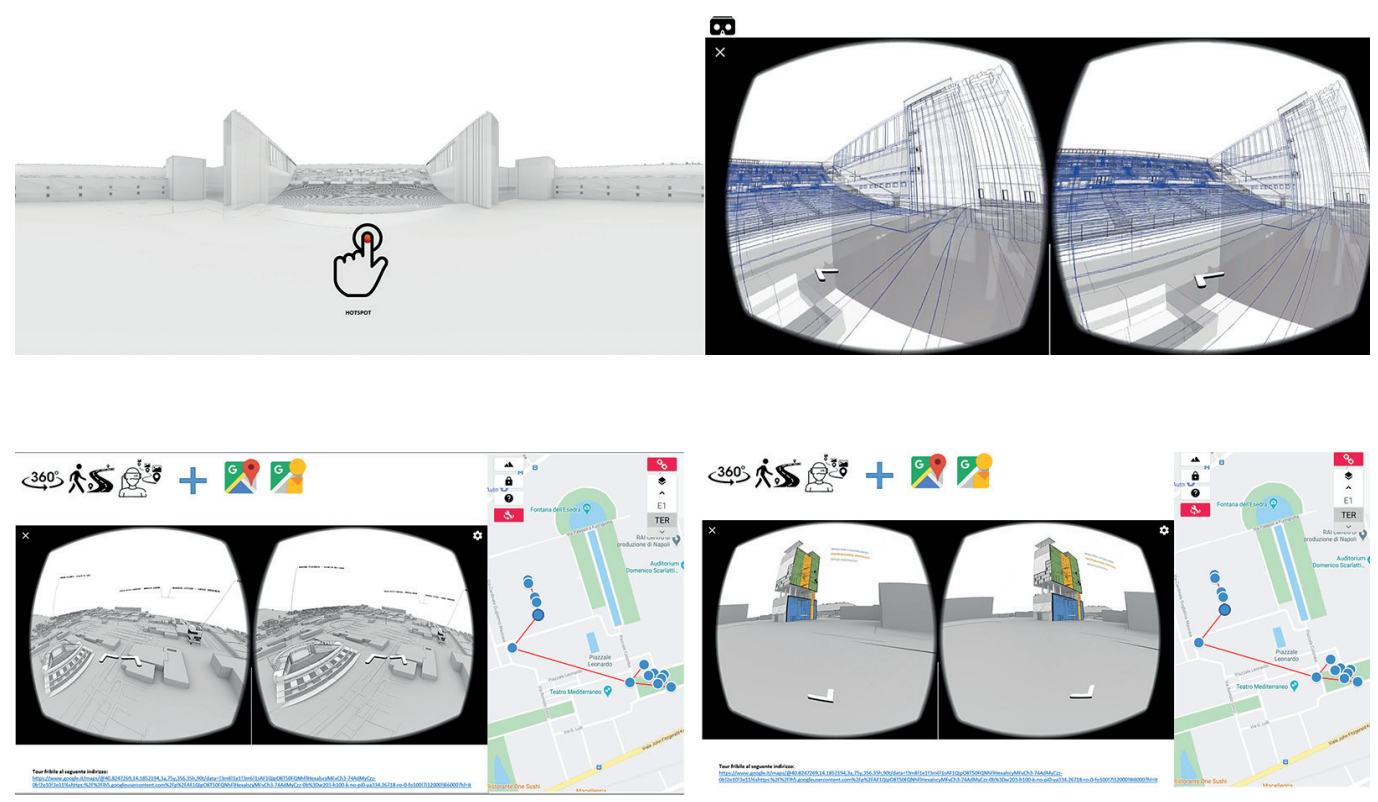
We shared some simulation tests to evaluate interoperability. These examples are accessible on Google maps, by activating the Street mode at the address Naples, Mostra d'Oltremare, Viale Kennedy (fig. II).

\section{Conclusions and future research}

The research aim is a web-based information system to represent the history of a site using languages, levels of simplification and interaction that can be changed according to the user and / or the context. We are going to test the use of some existing plug-ins that allow you to interact with the model using specific predefined control widgets, game controller touch, to experiment with the communication methods typical of games in cultural context (fig. 12) [Khan 2020].

In our research we intend to explore different ways of engagement able to stimulate the understanding of contents related to cultural heritage.
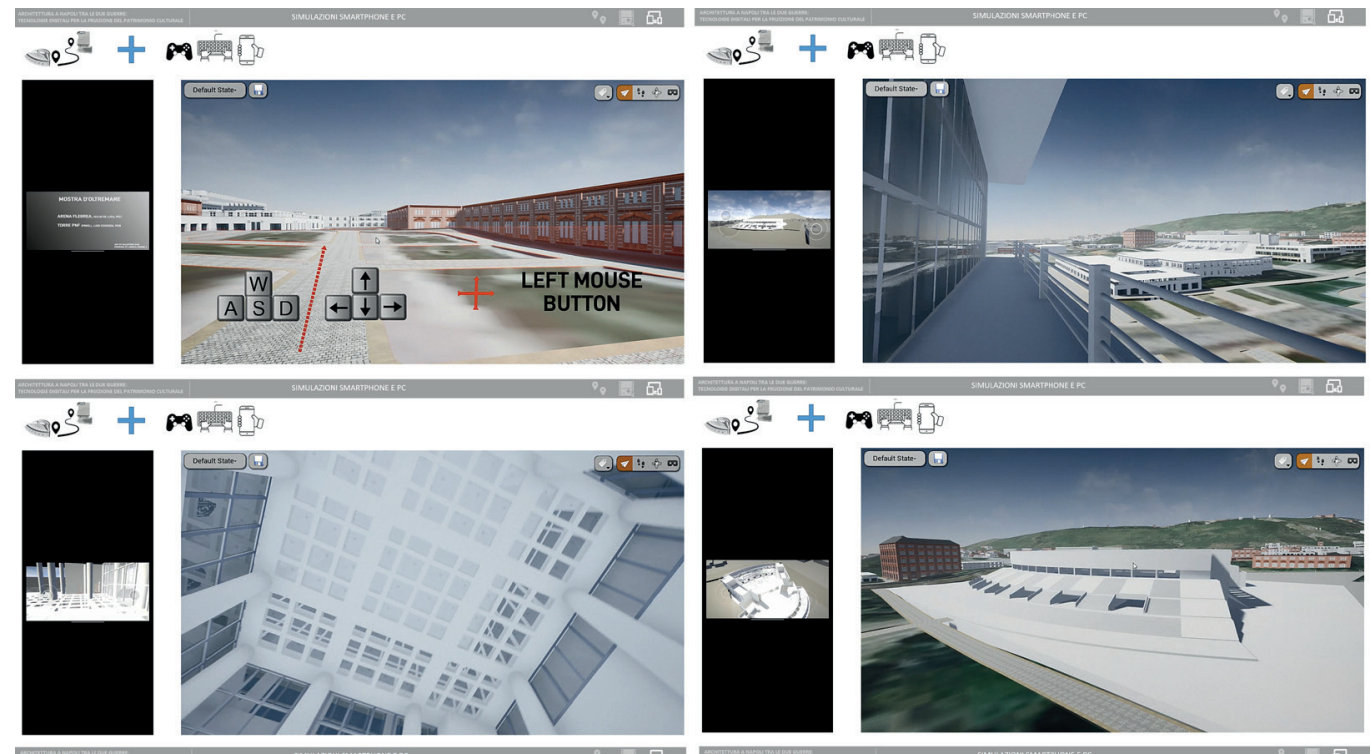
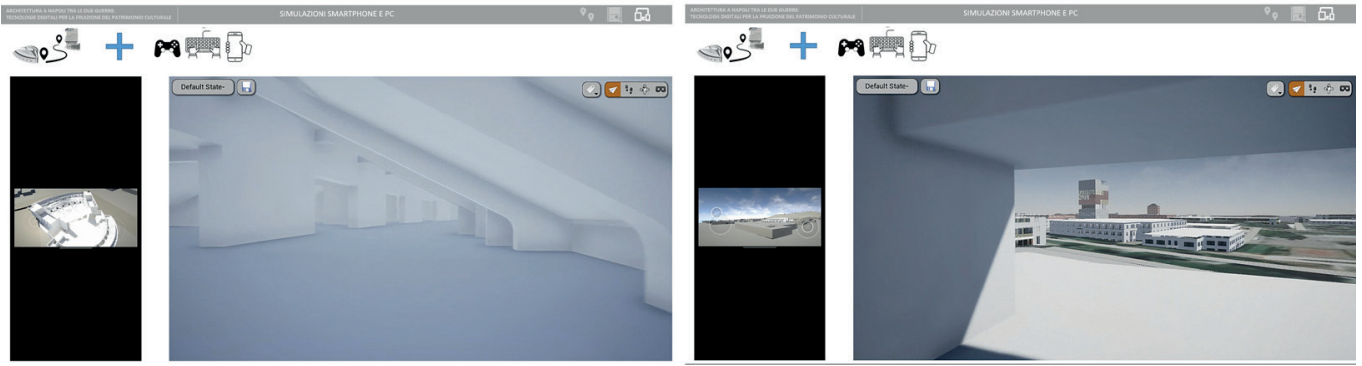

\section{References}

Carbone M. (2020). L'interfaccia uomo macchina nell'Industria 4.0. <https://www.industry4business.it/industria-4-0/linterfaccia-uomo-macchina-nellindustria-4-0/ > (accessed 202I, May 20).

Checa D., Bustillo A. (2020). A review of immersive virtual reality serious games to enhance learning and training. In Multimedia Tools and Applications, n.79(9- I0), pp. 550 I-5527. <https://doi.org/l 0. I007/s I I 042-019-08348-9> (accessed 2021, May 20).

Khan I., Melro A., Amaro A.C., Oliveira L. (2020). Systematic Review on Gamification and Cultural Heritage Dissemination. In Journal of Digital Media \& Interaction, vol. 3, n. 8, pp. I9-4I. 
Mortara M., Catalano C.E. (2018). 3DVirtual environments as effective learning contexts for cultural heritage. In Italian Journal of Educational Technology, n.26(2), pp. 5 -21.< https://doi.org/I 0. 1747//2499-4324// 026> (accessed 2021, May 20)

Pescarin S. (2020). Videogames, ricerca, patrimonio culturale. Milano: FrancoAngeli.

Interfacce grafiche, dinamiche e gamification. (2020, July 21). <https://www.gamification.it/gamification/interfacce-grafiche-dinamiche-e-gamification/\#more-> (accessed 202I, May 20).

\section{Authors}

Mara Capone, Università degli Studi di Napoli Federico II, mara.capone@unina.it

Emanuela Lanzara, Università degli Studi di Napoli Federico II, emanuela.lanzara@unina.it

To cite this chapter. Capone Mara, Lanzara Emanuela (202I). Artefatti cognitivi interattivi web-based: edutainment per il patrimonio culturale/ Web-based Interactive Cognitive Artifacts: Edutainment for Cultural Heritage. In Arena A., Arena M., Mediati D., Raffa P. (a cura di). Connettere. Linguaggi Distanze Tecnologie. Atti del $42^{\circ}$ Convegno Internazionale dei Docenti delle Discipline della Rappresentazione/Connecting. Languages Distances Technologies. Proceedings of the 42th International Conference of Representation Disciplines Teachers. Milano: FrancoAngeli, pp. 2119 -2 I 36. 